\title{
Einheit von Forschung und Lehre: Implications for State Funding of Universities
}

\author{
Nicoline Frølich ${ }^{\mathrm{a}}$, Kelly Coate ${ }^{\mathrm{b}}$, Stephanie Mignot-Gerard ${ }^{\mathrm{c}, \mathrm{d}}$ and \\ Christoph Knill ${ }^{\mathrm{e}}$ \\ ${ }^{a}$ Norwegian Institute for Studies in Innovation, Research and Education (NIFU STEP), \\ Wergelandsveien 7, Oslo N-0167, Norway. \\ ${ }^{\mathrm{b}}$ Centre for Excellence in Learning and Teaching (CELT), National University of Ireland, Galway, \\ Ireland. \\ 'IAE Gustave Eiffel, Université Paris 12, Paris, France. \\ ${ }^{\mathrm{d}}$ Centre de Sociologie des Organisations, Sciences Po, CNRS, Paris, France. \\ ${ }^{\mathrm{e}}$ Department of Politics and Management, University of Konstanz, Konstanz D-78467, Germany.
}

The Humboldtian educational ideal is based on the idea of the unity of teaching and research in universities (Einheit von Forschung und Lehre). The role of the state, according to Humboldt, was to fund universities in such a way that their autonomy was maintained. Much has changed in the funding mechanisms of higher education systems since the time of Humboldt, and here we consider developments within France, Germany, Ireland and Norway. Recent governance and funding reforms of higher education in Europe share the Humboldtian goal of promoting the 'very best education' through reconfigured relationships between the state and universities. However, most reforms which have taken place (and possibly those that are about to take place, as in the case of Ireland) have developed different external mechanisms to improve quality in teaching and research. The separation of funding for teaching and research has been a predominant approach which challenges the idea of unity of teaching and research, a key element of the Humboldtian model.

Keywords: humboldt; bologna; funding; managerialism; university governance

\section{Introduction}

Humboldt's view on the organisation of the university and the university-state relationship has been influential within European higher education systems. Recently the Bologna process has, to varying degrees, reshaped the relationship between universities and the state throughout Europe. Both Humboldt and Bologna entail strong visions of convergence in European higher education systems. 
In this article we will explore whether Humboldtian ideas of the university, notably the idea of unity of teaching and research, can be considered to be related to the allocation of state funding of universities in four countries: Ireland, France, Germany and Norway. The history of each of these countries differs with regard to how universities and their relationship with the state initially aligned with Humboldtian ideas. While the arrangements in Germany reflected the Humboldtian ideal model, the Irish higher education system was fairly Humboldtian in practice although Humboldt was not particularly inspirational. Both Humboldtian and French inspirations can be found in the discussions on how to structure the first Norwegian university; and while the French case was inspired by the Napoleon state administration, Humboldtian ideas were not particularly influential.

In Norway, the question can be asked as to what extent performance-based funding put in place as part of the 'Bologna package' interact with the Humboldtian understanding of the university organisation with regard to teaching and research. In France and Ireland, funding mechanisms have been decoupled from the Bologna process, but for different reasons as we will go on to discuss below. In Germany, increasingly new managerialism gains importance. One common thesis between France, Germany and Norway is that recent changes of university funding policies have fundamentally altered the relation between the state and the university, thereby undermining the idea of autonomous universities. However, the situation is complex as in the case of France, where recent reforms in state funding have increased institutional autonomy at the expense of the autonomy of individual academics. All of these changes suggest that Humboldtian ideas have potentially been eroded in these higher education systems. It may be the case that it in some countries the changes were not brought about by Bologna, but rather by public sector reforms aligned with new managerialism. Hence the article departs from the observation that the four countries seemingly diverge both regarding the influence of the Humboldtian ideas of the state-university relationship and regarding to what extent implementation of the Bologna process is coupled with new managerialism.

In more concrete terms, we explore the following questions:

- How did the university systems in Ireland, Germany, France and Norway initially align with Humboldtian ideas on funding of universities?

- To what extent have Bologna-inspired funding reforms altered the functioning of Irish, German, French and Norwegian universities regarding the unity of teaching and research?

- How have these changes made an impact on the Humboldtian aspects of the Irish, German, French and Norwegian universities, notably with regard to the unity of teaching and research? 


\section{The Humboldtian Starting Point and the Bologna Intervention}

Einheit von Forschung und Lehre formed part of the basic principles of the Humboldtian idea of the university which had implications for the organisation of the state-university relationship in general and in particular for the structuring of state funding of universities.

Humboldt was strongly in favour of universities as autonomous institutions with the role of promoting Bildung through science, truth and the unity of teaching and research. His view was of the university as an organisation of people that come together to cultivate science and Bildung as a means in itself. To Humboldt the student had an individual obligation to strive for Bildung. This individual obligation corresponds to Einsamkeit und Frieden as the central organisational principles of the university. Einsamkeit referred to the individual ability of independent thinking in cooperation with others (students and teachers). In this view freedom was a necessary condition for Bildung. On the individual level freedom referred to Lehr-und Lernfreiheit which protected the students' and teachers' choices of subject areas to pursue. Lehr-und Lernefreiheit at the individual level corresponded to academic freedom on the level of the university. The academic freedom of the university was seen as an organising principle that protected Lehr-und Lernfreiheit thus promoting Bildung (Brandser, 2006).

Regarding the relationship between the state and the university, Humboldt's view was fraught with tensions. Essentially in Humboldt's view the state represented the foremost challenge to the university, as state regulation implied loss of freedom. He insisted that the university should 'von allem Formen in Staate losmachen' (Humboldt, 1964 (1810), 31). However, the state was also the only body that could safeguard the university organisation (i.e. buildings, administration and funding). According to Humboldt, the role of the state was to guarantee the autonomy of universities. In his view the individual obligation to strive for Bildung entailed obligations on behalf of the state to cater for Bildung, Weisheit und Tugend (education, wisdom and virtue) (Humboldt, 1793 (1860), 235-236). Yet Humboldt (1850) insisted on minimal state interference and emphasised the role of liberty in individual development and the pursuit of excellence. Based on this Humboldt suggested that the state funded the university on an annual basis.

Currently European higher education is adapting to the Bologna process, which is perhaps bringing a more bureaucratic vision to higher education. The Bologna process aims to create a 'European higher education area' through more comparable and compatible national academic degrees and quality assurance standards. According to the declaration academic degree structures should be based essentially on two main cycles, undergraduate and graduate, with the first cycle lasting at least 3 years. ' The ECTS (European Credit 
Transfer and Accumulation System) has been introduced to enable credits to be compared across European higher education systems. The introduction of external standards for quality assurance in higher education also forms part of the Bologna process.

In addition to these teaching and learning measures at the core of the Bologna process, several countries have introduced governance reforms in higher education more or less as 'riders' to the implementation of the Bologna declaration itself. These supplementary reforms include among others the introduction of tuition fees and the restructuring of universities, as is the case in Germany. In some countries, notably Norway, the allocation of state funding of universities has even been altered as part of 'the Bologna package'. These changes have included the introduction of performance-based funding, and competitive procedures aimed at improving quality and efficiency.

Humboldt and the Bologna documents share the vision of promoting excellence in higher education; however, the views of the organisations of the state-university relationship diverge. In order to illustrate how national systems have diverged from Humboldt in response (or otherwise) to the Bologna process, we will now turn to our four country case studies.

\section{Humboldt's Vision: Departures}

\section{Ireland}

Humboldt's period of influence was perhaps overshadowed in Ireland by the arrival of John Henry Newman. Newman was the founding rector of the Catholic University of Ireland in 1854, which later became part of University College Dublin (now the largest of the seven universities in Ireland). Newman and his founders intended to provide a Catholic alternative to the first, Anglican, university in Ireland, Trinity College Dublin, which had been established through a charter from Queen Elizabeth I in 1592. Newman's book, The Idea of the University (written in 1852), is widely perceived to be a treatise in favour of liberal education, but differs from Humboldt's vision in that he believed that universities should teach but not conduct research. An important distinction here is that Newman was not a scientist but a religious figure, and although he argued that teaching should help provide wisdom, he was not arguing in favour of the pursuit of new knowledge or truth through critical thought.

Although Newman is widely respected in Ireland, the higher education system is more Humboldtian in character than Newman would have preferred. Especially since the foundation of the 'godless' Queen's Colleges in the 19th century, the system has evolved to allow universities to enjoy a great degree of freedom from religion and the state (Coate and Mac Labhrainn, 2009). 
Universities have also become important sites of research production another development of which Newman would have disapproved - and which was given an enormous boost through the Celtic Tiger economy. The religious sentiments which inspired Newman's thoughts on the shaping of individual characters (his version of Bildung) have not been a feature of the system given that only one university (University College Dublin) has in any way been historically regarded to be a 'Catholic' university (Lydon, 1991). Therefore, the Humboldtian ideals of freedom from the state and religion, the pursuit of scientific enquiry, and the formation of individual character through facilitating self-realisation are all characteristic, to some degree, of the Irish higher education system. Yet the Irish have not tended to claim Humboldt as their inspiration, but rather have shown more sympathy with the Catholic priest who came to their shores.

\section{France}

At the time when Humboldt was building the foundations for a university based on the autonomy of knowledge production and transmission, Napoleon was creating the Université impériale in France, which was organised in two sectors: professional schools were built in the fields of law and medical science, whereas the role of humanities and sciences was limited to conferring degrees.

Humboldt subsequently began to attract interest in France. Louis Liard advocated for the revival of the French university in 1886 strongly inspired by the Humboldtian ideal (Charle, 1994). However, the implementation of the reform was unsuccessful: research remained a minor activity compared to the missions of teaching and degree graduation; and the underlying ideal of the pursuit of science in the Humboldtian model was not shared by the whole community of scholars in France which remained divided according to the norms and practices framed by the Napoleonic model (Musselin, 2004). The only shared objective among academia was to gain independence from the state and the society (Weisz, 1983). To do so, all the careers and salaries would be administrated by national commissions of disciplinary peers rather than by the universities (Musselin, 2004).

French higher education remained largely unchanged until 1968 when the $l o i$ Faure of 1968 and the loi Savary in 1984 aimed at improving the capacity of collective action of universities. However their influence was limited. The reforms aimed at restructuring university governance, but neither state funding of universities was introduced nor was the 'corporatist-centralised' model of professional regulation challenged.

In the late 1980s 4-year contracts were introduced between the universities and the Ministry. Through this policy universities negotiate a small part of 
state funding on the basis of the strategic plans drawn by the institution for the next 4 years. Albeit a subtle change, the contracts between the universities and the ministry entailed significant modifications in weakening the disciplinebased logic of intervention of the ministry and promoted the recognition of universities as relevant actors within the French higher education system (Musselin, 2004).

\section{Germany}

The Humboldtian model is often referred to as the 'German model' and in the 19th century the organisation of German universities was fully in line with Humboldt's ideal. In 1810, Humboldt convinced the King of Prussia to build a university in Berlin (today's Humboldt University) based on Friedrich Schleiermacher's liberal ideas. The university aimed at introducing the students to the process of knowledge discovery, teaching emphasised the fundamental importance of 'the laws of science'. In line with Humboldt's principles the university was characterised by self-governing communities of scholars, weak university management and strong professorial dominance and collegial control (Dobbins and Knill, 2009). The model was based on a stateuniversity partnership, governed by principles of corporatism and collective agreement.

The German universities were mainly funded by the state, and university professors were state functionaries. The German Länder were responsible for the appointment of professors and the funding of the universities' teaching and research activities. As a consequence the universities had limited selfgovernance, but the state allowed the universities to establish normative principles of their own (Olsen, 2007, 29). The university was committed to the search for truth through intellectual freedom - regardless of its immediate utility or political convenience. Collegial governance through the professorial chair system, in which each chair constitutes a core organisational unit, was an essential element of the way universities were organised (Schimank, 2002, 8; Dobbins and Knill, 2009).

The university model remained largely unchanged despite the fundamental changes in the German political system caused by two world wars. The influence of the state grew over the years which implied that universities had little autonomy regarding funding and appointments of professors (based on a list of candidates selected by the university). Within these limits the universities enjoyed broad freedom in research and teaching. University budgeting had to follow strict rules in line with public budgets in general. As a consequence universities were not allowed to introduce financial incentives to improve performance, to freely transfer financial means across budgetary years nor to rely on economic cost calculations (Hartmann, 2006). 
The federal level is involved in particular in the funding of research (via the Deutsche Forschungsgemeinschaft) and the co-financing of construction and maintenance of universities. The dominant role of the state also implies that German universities enjoy limited room for manoeuvre regarding acquiring private sector funds. While other European universities, especially in the context of reduced state funding, tried to offer research and teaching as a service in the private sector, this was not an option to German universities (Pritchard, 2006; Dobbins and Knill, 2009).

\section{Norway}

At the time when the first Norwegian university was established in 1811, Humboldtian ideas were influential. However ideas from the Enlightenment and the French revolution pointed in the direction of establishing an Academy devoted to technology and economics. But in the end in line with Humboldt and 'new-humanism' it was asserted that Norway as a young nation needed a full university to develop into a 'cultivated' state. A more pragmatic reason to establish a full university in 1811 was the objective of educating public servants (in Norway and not Denmark) to the Norwegian state administration (Collet, 1999, 23-45).

Despite the Humboldtian influence and the ambition to found a full university in Oslo, in the first decades the university was first and foremost an educational institution with few scientific underpinnings (Collet, 1999, 56). However, the influence of the Humboldtian University and of Einheit von Forschung and Lehre grew and during the last decades of the 19th century the university underwent reforms in the functioning of teaching and research activities. The students successfully claimed that fixed educational programmes should be put in place and faculty members strived to improve the research conditions. At this point in history, one main issue on the university policy agenda was to challenge the dominance of public administration over the university (embetsmannsstat) and to improve the conditions to conduct free research. The first rector of the University of Oslo, appointed in 1905, pointed out that state funding of the university did not promote the conditions for free and independent research. In his view the university should rather be funded by gifts to maintain its autonomy with regard to the state (Collet, 1999, 100-112).

Until the 1980s, funding of the universities was largely based on the establishment of new academic positions, most notably professor positions, and the professors themselves enjoyed the position of being an embetsman. University budgets were fixed and detailed and the universities did not have much room for manoeuvre regarding how the budgets were spent. 


\section{Introducing Bologna}

\section{Ireland}

In the same way that Humboldt's ideas were not a defining influence on Irish higher education in the way they were elsewhere on the continent, the Bologna process too has not played a major role in the shaping of the contemporary higher education system. As with Humboldt, the lack of explicit influence does not imply a lack of conformity: the degree structures were Bologna compliant before Ireland signed up to the Bologna process, and ECTS were fairly easily adapted across the system. The Irish system is therefore widely regarded to be largely compliant with the Bologna process (Stengel, 2009), and so changes in the funding system were driven by other factors.

Funding reforms have therefore not been introduced in the Irish higher education system as a result of the Bologna process, nor are they likely to be. Irish universities receive approximately $90 \%$ of their funding from the state, and this is core funding for teaching and research which is not tied to performance. During the 1990s and up until very recently, the Celtic Tiger economy enabled the government to introduce research funding streams which greatly enhanced the research performance of Irish universities. Some of this funding is awarded on a quasi-competitive basis, in that universities make collaborative bids to undertake proposed projects, but the funding is awarded on the merits of the proposed projects and therefore most funding streams are allocated on a prospective (inputs) rather than retrospective (outputs) basis.

Now that the Celtic Tiger has waned, there is much discussion of how to ensure that university funding is transparent, accountable and value for money. In other words, a weak version of new public management is creeping into the Irish system (Clancy, 2007), although this may have more bite as the credit crunch becomes more severe. At the moment, any proposed plans in funding reforms are not known, as a review group has been charged by the Minister of Education with devising a National Strategy Review for Higher Education in Ireland. The Review group has been given the remit to propose means for 'rationalising' the higher education system and ensuring greater efficiency. However, this process has been divorced from the Bologna process entirely, which is widely perceived to be only a matter related to teaching and learning strategies (e.g. the production of learning outcomes, standardisation in the use of ECTS, and the introduction of competence-based learning).

\section{France}

France implemented the Bologna process early: the first laws to change the degree structure were published in April 2002 and the new scheme was put in place in all the universities by the end of 2007 . 
At the same time in 2006 and 2007 two major laws were promulgated: The loi pour la Recherche (law on Research) and the loi relative aux Libertés et Responsabilités des Universités (loi LRU) (law on Liberties and Responsibilities of Universities). However, the relationship between these laws and the Bologna process is heavily debated. According to some authors the national and European public policies are guided by the same 'market conception' of higher education (Caille and Vatin, 2009) while other authors assert that the laws mainly address national problems (Musselin, 2005). Some authors also point out the influence of other international events with regard to the decisions made in France. Caille and Chanial (2009) posit that the Shanghai ranking and the need to increase the French universities' international competitiveness have guided the reforms led by Sarkozy and his government.

The two laws introduced changes in university funding. A new agency (l'Agence Nationale pour la Recherche) was introduced in 2005 to fund research on a competitive basis after peer-review evaluations. With the loi $L R U$, all the resources granted by the state will be integrated into the 4-year contract negotiation; more importantly, the universities will now pay the salaries of their staff. All these resources are integrated into a global budget that allows universities to transform mutual credits into positions. Previously, state allocations to universities did not include university staff salaries. In the former budgets, $80 \%$ of the resources were calculated on the basis of quantitative criteria reflecting the activity - measured for the most part by the number of student enrolments. The remaining $20 \%$ of resources were allocated through the negotiation of the 4-year contract between the university and the ministry based on plans and priorities set up by the institutions.

Increasingly new managerialism and the notion of performance have gained importance in France. In June 2008 the Senate released a report introducing several measures that push in this direction (Adnot et al., 2008). In relation to teaching, the suggestion is to base $10 \%$ of the state funding on qualitative results (success rate in exams or the placement of graduates in the job market). Another suggestion is to allocate funding based on the number of students passing exams rather than basing the budget on the number of students enrolled. Regarding research it is suggested that $20 \%$ of the funds should be allocated based on 'performance', but the indicators to be used for quality assessment are not yet developed.

\section{Germany}

German higher education was long considered resistant to significant change because of its complex and segmented decision-making structure. However during the last decade important legal and political changes have been introduced aimed at responding to globalisation, internationalisation and 
increasing competition. Amendments in the Federal Framework Law on Higher Education (Hochschulrahmengesetz) in 1998 and in the Higher Education Laws at the Länder level in 2002 point in this direction. The Bologna process and the growing importance of new managerialism in German higher education policy are important drivers of these reforms. In the German context new managerialism and the Bologna process is strongly intertwined. Also benchmarking reports of the OECD (in which Germany with regard to many aspects emerged as a higher education laggard) profoundly changed the domestic reform context (Welsh, 2004; Dobbins and Knill, 2009).

The changes implied significant shifts from a centralised input-based funding system towards a more decentralised and autonomous system. All Länder introduced higher education pacts or contracts between governments and universities to improve the conditions for long range planning. The contracts ensure financial planning on behalf of the universities (during an election period). In return, the universities accept some financial cuts. German states increasingly rely on performance-based and capacity-related allocation of funding, although input-based funding still remains by far the dominant source of funding for German universities. At the same time, a large number of decisions regarding staff, appointments, examinations and internal management were assigned to the universities (Hartmann, 2006; Pritchard, 2006).

The implementation of the Bologna process - in addition to respective adjustments of study programmes, accreditation structures and ECTS - was accompanied by the introduction of moderate tuition fees as additional source of university funding in order to improve the study and teaching conditions in German universities, hence making them more competitive at the international level. This highly politicised development has so far only taken place in states with a conservative government coalition. The tuition fees are designed to improve student support and the range of courses offered (Welsh, 2004).

Concerns regarding the international competitiveness of German higher education rather than the Bologna process pushed in the direction of the socalled excellence initiative. In the context of this large-scale programme, managed jointly by the federal and state level, national universities can compete for mid-term additional funding. The allocation of funds basically rests on a peer-reviewed assessment of university applications for graduate schools, clusters of excellence or overall concepts for university-based top-level research. Based on this programme, nine German universities have thus far been labelled 'universities of excellence'. In addition to huge additional funds this status - this is at least the general conception - should help to significantly increase their national and international reputation. At the same time, the excellence initiative for the first time led to a competition between national universities and - and related to this - the higher education policies of the Länder (Hartmann, 2006; Dobbins and Knill, 2009). The allocation of 
funds and excellence labels is not free of political conflicts, in particular because of the fact that there so far is a clear dominance of universities in the Southern states of Baden-Württemberg and Bavaria.

\section{Norway}

In line with several Western democracies, Norway introduced new managerialism in public administration including the higher education sector from 1980 onwards (Frølich, 2005). Promoters of the restructuring of state budget procedures asserted that greater efficiency was the only road to improvements in the public sector, and that incentives for more efficiency should be included in the budget system. Universities were seen as having an obligation to 'meet the needs of the market' and Management by Objectives (MBO) was introduced as an instrument to follow these requirements.

New managerialism was much debated in Norwegian universities and it provoked resistance. Concerns were expressed that MBO introduced market mechanisms that broke with the value base of universities. In the view of the academics universities operated according to a different logic, which was not amenable to this form of governance (Frølich, 2005).

Twenty years later a comprehensive reform of higher education was introduced, largely in line with the Bologna implementation: the Quality Reform project. As part of this reform, performance-based funding of universities was strengthened. In general, concerns about the cost- effectiveness of higher education, and the aim of stimulating student progression and enhancing the development of new, attractive study programmes, legitimated the introduction of performance-based funding. The previous funding system mainly based on lump-sum funding was seen as the cause of structural imbalance between funding for research and teaching. The main argument was that research funding had been far too closely linked to education and the number of students, allowing for too little discretion in the separate funding of research according to its particular needs and considerations. Promoters of the reform held the view that quality considerations in education and research were best safeguarded by means of a financing system that emphasised the results attained and by introducing a partial distinction between teaching and research in the calculation of budgets (Frølich, 2010; Frølich et al., 2010).

Performance-based funding was therefore seen to focus attention on 'production': the number of students completing programmes and the number of publications generated by research activities. Key actors in higher education argue that performance-based funding potentially will result in improved student recruitment and efforts to promote student completion. With regard to research, it was foreseen that concentrating activities on larger research programmes and international contacts would improve the quality of research. 
Critiques of the reform maintain that the reform favoured institutions with many students in each programme, making it difficult for institutions with a small number of students in each programme to maintain a sound financial position. Concerns were raised that universities may find it more attractive to conduct mainstream research, which is more easily published in journals, than pioneering, critical and creative research (Frølich, 2010; Frølich et al., 2010).

\section{Comparing Bologna and Humboldt}

\section{Ireland}

Irish universities are arguably on the brink of experiencing a new public management-style agenda. Until now, they have enjoyed a remarkable degree of academic autonomy. One question which has arisen as a result of the changes in society brought about by the Celtic Tiger is what purpose universities serve: the needs of the knowledge economy have been a strong driver shaping university activities (Coate and Mac Labhrainn, 2009). An emphasis on science, engineering and technology gave an important boost to the economic activities of the country.

However, the new Minister of Education seems to be taking the view that universities are not offering the output that is desired. A recent report by a government-appointed committee (McCarthy, 2009) tasked with recommending cuts in public expenditure has stated that there is no evidence that the significant amounts of research funding in the previous decade resulted in tangible outputs. They therefore recommended that large streams of research funding be halted. The government will be considering these proposals and will not necessarily adopt them, but the new focus on outputs is a strong indication that Ireland may experience the types of public sector reforms seen elsewhere. In the meantime, the Department of Finance, through the Higher Education Authority (the funding body for the higher education sector), has taken a drastic step of its own by imposing an Employment Control Framework on the sector, which is a recruitment and promotions moratorium. No new staff posts, contract renewals or promotions can be made by universities without the permission of the Minister for Finance. This moratorium arguably contravenes the Higher Education Act of 1997 and it remains to be seen whether the universities will successfully argue for its removal.

Whatever the outcome of these measures during the current economic crisis, it is clear that the continued autonomy of universities is being called into question. Public sector reforms elsewhere have similarly involved a greater degree of state control (new managerialism) over the ways in which funds are spent in the public sector. However, in the case of Ireland, these reforms are unrelated to the Bologna process but are driven by the current economic and political climate. 


\section{France}

In the past 4 years, the political agenda for the French higher education system has been remarkably volatile. The protests that erupted in universities in 2009 reflect a turning point in the relation between the state, the universities and the academic profession.

The bureaucratic model of public funding to universities that was predominant in the past is currently eroded by the emergence of indicators of academic quality and economic performance in the funding formulas used by the state. The national agencies created to assess the quality of teaching and research programmes and distribute the credits accordingly signal an increase of the control exerted by the state. In addition to the call for greater efficiency in the distribution of the state funding, the universities are being encouraged to improve the management of those resources.

The recent reforms potentially challenge the autonomy of the academic profession. Now, university presidents can block decisions to recruit and promote faculty members. In addition, faculty members have less control over the balance of their research and teaching activities. Before the loi $L R U$, the teaching loads of the permanent faculty staff were uniform: all had to complete $192 \mathrm{~h}$ of teaching per year; the rest of the time was supposed to be dedicated to research. A decree of the $L R U$ plans that each faculty will now negotiate the balance between teaching and research with administration. Faculty have thus lost autonomy as the institutional leadership gain increasing latitude to adapt human resources to their perceived needs. Indeed, the decisions made by the university administration will be based on the performance of individuals in the domain of research: faculty who perform well in research will be able to negotiate a reduction of their teaching loads, whereas low performers in research could be obliged to teach more courses. The decree is all the more disputed in that it may decouple research from teaching.

Still, the scenarios for the future remain unclear. Some of the reforms that we described here were merely projects of laws; others were just voted a few months ago and not implemented yet. We thus still lack the necessary distance to study the concrete consequences of these reforms in the universities and their sub-units.

\section{Germany}

From its very beginning German higher education governance essentially in line with the Humboldt ideal. However the German model partly diverges from the ideal model notably concerning the strong intervention of the state in financial and personnel decisions of the universities. To some extent these 
aspects of the German practice entailed limitations in the ideal of academic freedom.

During the last decade important transformations in German universities took place which additionally separates the German universities from the Humboldtian model. These changes are primarily driven by concerns of international competitiveness and overall changes in public sector management ideas. The Bologna process in this context can be seen as a catalyst rather than reform cause of its own. We observe a shift from an input-oriented model of detailed governmental management to an output-oriented model characterised by the use of target-oriented funding based on performance parameters and the introduction of instruments of business administration such as target agreements and cost and activity accounting. This development coincides with a strong emphasis of inter-university competition both at the federal and state level.

These increases in the financial autonomy of the universities to some extent could be interpreted as the full realisation of Humboldtian ideas. However, autonomy gains come at a certain price, namely the introduction of marketbased approaches of competition and performance evaluation.

\section{Norway}

Humboldtian ideas on Bildung and academic freedom seem to have been on the university policy agenda since the very establishment of the first Norwegian university. There seems to have been continuous debates on the relationship between the state and the university throughout the $1800 \mathrm{~s}$ up to the $1980 \mathrm{~s}$. The essential questions have turned around issues such as: what does state funding of universities imply in relation to academic freedom? How can free and independent research be fostered? What is the main aim of university education, Bildung or usefulness?

Norwegian universities were part of the public administration exposed to new managerialism during the 1980 s and measures were put in place to improve the effectiveness of the university functioning. This agenda seems to have been strengthened in the Norwegian implementation of the Bologna process which emphasised the political belief in performance-based funding as a means to improve the functioning of the university. Arguably, performancebased funding reshapes the relationship between universities and the state more fundamentally than previous funding policies in Norway.

\section{Discussion and Conclusion}

Einheit von Forschung und Lehre was an essential organising principle in the pursuit of Bildung in the Humboldtian vision. The role of the State according 
to Humboldt was to fund universities in such a way that university autonomy was enhanced thus promoting Bildung. French, Irish, German and Norwegian universities were at the time of Humboldt similar in that they were more or less fully funded by the state. However, at the time of Humboldt, neither French nor Irish universities were organised in line with Humboldt's perspective. In France the educational function of the universities was essential to their raison d'etre, the research function was organised in separate research units. In Ireland, Humboldt proved to be more influential in practice than the religious leader normally portrayed as the founding father of the Irish universities. Also the research function of the Irish universities was more prominent than in France. Although the Norwegian universities were influenced by the Humboldtian ideas, they were first and foremost educational institutions and had to fight for the research function to become more prominent. In Germany, by contrast, the system was very much in line with Humboldtian ideas, notwithstanding certain restrictions on university autonomy emerging from tight state control.

Performance-based funding introduced in several European countries as part of the Bologna package questions the idea of Einheit von Forschung und Lehre by an increasing separation of funding for research and teaching. Arguably also the accountability schemes increasingly put in place diverge from the Humboldtian idea of autonomous universities. Again France, Ireland, Germany and Norway diverge in the degree to which their funding reforms were inspired by Bologna and in the implementation of new managerialism. French universities have, despite the contractual agreements between the universities and the state since the late 1990s, remained closely coupled to the state in budget matters. Only recently has France tied funding more explicitly to performance while Ireland has only yet experienced a 'light touch' of new public management measures. In comparison with the two other countries, Norway established quite early a comparably encompassing performance-based funding model rewarding research publications, credits and graduates. A similar pattern can be observed for Germany, where concerns of international competitiveness together with managerial reform ideas and Bologna concepts triggered far-reaching moves towards performance-based funding schemes.

Comparing the four countries there is also a striking decoupling in Ireland and France between funding reforms and Bologna (for different reasons however), whereas Germany and Norway in this context seems to have taken the opportunity of Bologna to put at the front the issue of quality. Moreover, in Norway and Germany, which are the most 'Humboldtian' cases of this article, the Bologna process seems to have been coupled with attempts to strengthen new managerialism, whereas France and Ireland where the Humboldtian ideas did not become that embedded, the Bologna process 
remained a case of teaching and learning issues. Nevertheless, promoters of the four different funding models would probably agree that the aim is to promote 'the very best' research and education, as was Humboldt's aim with promoting the idea of Bildung.

\section{Note}

$1 \mathrm{http} / /$ ec.europa.eu/education/policies/educ/bologna/bologna.pdf.

\section{References}

Adnot, P., Dupont, J.-L., Gaudin, C., Lagauche, S., Longuet, G. and Richert, P. (réd.) (2008) Rapport d'information sur la réforme de l'allocation des moyens par l'Etat aux universités, Sénat; $n^{\circ} 382$ Les rapports du Sénat, Paris: Sénat.

Brandser, G.C. (2006) 'Humboldt revisited. The institutional drama of academic identity', Ph.D. dissertation, Department of Administration and Organization Theory, University of Bergen.

Caillé, A. and Chanial, P. (2009) 'Présentation', Revue du Mauss 33: 5-30.

Caillé, A. and Vatin, F. (2009) 'Onze modestes propositions de réformes de l'université', Revue du Mauss 33: 423-440.

Charle, C. (1994) La république des universitaires: 1870-1940, Paris: Seuil.

Clancy, P. (2007) 'Resisting the Evaluative State: Irish Academics Win the Battle but Lose the War', in J. Enders and F. van Vught (eds.) Towards a Cartography of Higher Education Policy Change: A Festschrift in Honour of Guy Neave, Enschede: CHEPS.

Coate, K. and Mac Labhrainn, I. (2009) 'Irish Higher Education and the Knowledge Economy', in J. Huisman (ed.) International Perspectives on the Governance of Higher Education: Alternative Frameworks for Coordination, New York: Routledge.

Collet, J.P. (1999) Historien om Universitetet i Oslo, Oslo: Universitetsforlaget.

Dobbins, M. and Knill, C. (2009) 'Higher education policies in Central and Eastern Europe: convergence toward a common model?', Governance 22(3): 397-430.

Frølich, N. (2005) 'Implementation of new public management in Norwegian universities', European Journal of Education 40(2): 223-234.

Frølich, N. (2010) 'Multi-layered accountability. Performance funding of universities', Public Administration 24(1): 7-21.

Frolich, N., Schmidt, E.K. and Rosa, M.J. (2010) 'Funding systems for higher education and their impacts on institutional strategies and academia: a comparative perspective', International Journal of Education Management (forthcoming).

Hartmann, M. (2006) 'Die Exzellenzinitiative - ein Paradigmenwechsel in der deutschen Hochschulpolitik', Leviathan 34(4): 447-465.

Humboldt, W. von $(1793,1860)$ 'Theorie der Bildung des Menschen. Bruchstück', in W. von Humboldt (ed.) Schriften zur Antropologie und Geschichte, Darmstadt: Wissenschaftliche Buchgesellschaft.

Humboldt, W. von (1850) On the Limits of State Action, E. Trewendt.

Humboldt, W. von $(1964,1810)$ 'Über die innere und aussere Organisation der höheren wissenschaftlichen Anstalten in Berlin', in W. von Humboldt (ed.) Bildung des Menschen in Schule und Universität, Heidelberg: Quelle \& Meyer Verlag.

Lydon, J. (1991) 'The Silent Sister: Trinity College and Catholic Ireland', in C.H. Holland (ed.) Trinity College Dublin and the Idea of a University, Dublin: Trinity College Dublin Press. 
McCarthy, C. (2009) Report of Special Group on Public Service Numbers and Expenditure Programmes, Dublin: Government Publications.

Musselin, C. (2004) The Long March of French Universities, New York, London: Routledge Falmer.

Musselin, C. (2005) 'Change and Continuity in Higher Education Governance? Lessons Drawn from Twenty Years of National Reforms in European Countries', in I. Bleiklie and M. Henkel (eds.) Governing Knowledge: A Study of Continuity and Change in Higher Education: A Festschrift in Honour of Maurice Kogan, Dordrecht: Springer, pp. 65-80.

Olsen, J. (2007) 'The Institutional Dynamics of the European University', in P. Maassen and J.P. Olsen (eds.) University Dynamics and European Integration, Dordrecht: Springer.

Pritchard, R. (2006) 'Trends in the restructuring of German universities', Comparative Education Review 50(1): 90-112.

Schimank, U. (2002) 'Governance in Hochschulen', Speech on the occasion of the event Professionelles Wissenschaftsmanagement als Aufgabe organized by the Zentrums für Wissenschaftsmanagement; 22 October 2002; Wissenschaftszentrum, Bonn.

Stengel, D. (2009) Botany teaching in Irish and German Higher Education Institutions: Historical aspects and an assessment of recent responses to the Bologna Process. Unpublished MA Thesis: National University of Ireland, Galway.

Weisz, G. (1983) The Emergence of Modern Universities in France: 1863-1914, Princeton: Princeton University Press.

Welsh, H. (2004) 'Higher education in Germany: reform in incremental steps', European Journal of Education 39(3): 359-375. 